\title{
Studies on recent IBD virus field variant isolates: Genomic identification and differentiation using RT-PCR-RFLP
}

\author{
M. M. Amer ${ }^{1}$, S. A.Nassif ${ }^{2}$ \\ ${ }^{1}$ Faculty of Veterinary Medicine, Cairo University, Giza, Egypt. \\ ${ }^{2}$ Central Laboratory for Evaluation of Veterinary Biologics, Abbasia, Cairo, Egypt
}

In the present study, 3 pooled proventricular homogenates were collected from 3 broiler flocks, of chicken 15 to 30 days old, from Monofia Governorate. The 3 flocks were suffered from low growth rate, poor feed conversion rate, uneven growth and increased mortalities. Necropsy of dead chickens revealed proventriculitis with increased proventriculus size. IBD viral antigen was detected in the pooled proventricular homogenate of each flock by AGPT using reference antibodies against IBDV and RT-PCR technique. No other viruses were detected; such as Reo virus, CAV, NDV, IBV and ALV-J. Further characterization of the IBDV isolates were conducted by RFLP assay on PCR products using MboI and BstOI restriction enzymes. Results demonstrate that the 3 IBDV isolates are identical in their RFLP pattern and related to the Del/E variant strain of IBDV.

Infectious bursal disease virus (IBDV) causes an immuno-suppressive disease in poultry leading to mortalities and heavy financial losses to the poultry industry. The virus initiates the destruction of lymphatic tissue in the bursa of fabricious. IBDV has also been implicated as a cause of the transmissible viral proventriculitis (TVP) in broiler chickens (Bayyari et al., 1995; Huff et al., 2001 and Newberry, 1996).

Classical strains of IBDV were found to produce transient lesion in the proventiculus of specific pathogen free (SPF) leghorns (Skeeles et al., 1998). Flattining of the papillae, haemorrage, exudate in the mucosal surface and grossly visible promenances on the seroasl surfaces were present. Neither proventricular necrosis nor enlargement.was detected. Variant IBDV strains play a role in the TVP, so that vaccination of broiler progony against these strains could be helpful in reducing the incidence and severity of the disesae (Dormitorio et al., 2000). In USA, variant strains of IBDV have been proposed as the possible etiology of proventriculitis (Cookson, 2001; Huff et al., 2001 and Giambrone, 2002). In EGYPT Del/E IBDV variant strain; as detected by an antigen capture ELISA kit; was suspected to be the cause of proventriculitis in 46 broiler flocks suffering from proventriculitis (Hussien et al., 2003). The economical impact of TVP could be summarized in higher than avarage mortality , stunted growth, poor feed conversion rate and passage of the undigested feed in the faeces of the affected chickens (McNulty, 1991 and Goodwin, 1993).

The objective of the present study was to detect, idendify and characterize IBDV strain that could be potential causative agent of TVP in broiler flocks in Egypt via using RTPCR - RFLP assay.

IBD viruses.

\section{Materials and Methods}

Field isolates. Proventriculi were collected from 3 affected broiler flocks. Samples of each flock were pooled, homogenized in a sterile phosphat buffer saline (PBS) as $10 \%$ $(\mathrm{w} / \mathrm{v})$, then exposed to 3 cycles of freezing and thawing, sample suspensions were clarified by centrifugation at $1200 \mathrm{xg}$ for 20 min. at $4^{\circ} \mathrm{C}$. The supernatant was collected and passed through $0.45 \mu$ then $0.22 \mu$ filters. Streptomycin $(100 \mathrm{mg} / \mathrm{ml})$ and gentamycin $(50 \mathrm{mg} / \mathrm{ml})$ were added to the filtrate. IBDV was detected in the prepared proventricular homogenate by AGPT using refrence serum against IBDV (Nassif, 2001). For confirmation of presence or absence of other viruses in the proventricular homogenate. Each preparation was checked for the presence of other virsues by inoculating the suspension into 20, one day old SPF chicks intra-ocularly and orally $(0.2 \mathrm{ml} /$ chick $)$. Chicks were observed for 2 weeks, sera were collected at the $14^{\text {th }}$ day post inoculation (PI) and tested for the presence of antibodies for IBDV, NDV, reo virus, CAV, IBV and ALT- 
$\mathrm{J}$ using commercial ELISA kits (IDEXX and KPL). ELISA results indicated presence of detectable antibodies against IBDV only.

Classical IBD virus vaccine. D78 vaccinal strain of IBDV (Intervet, Batch No. 011217D) was used. The lypholized vaccinal strain was reconstituted in $5 \mathrm{ml}$ TNE buffer (10mM Tris-Hcl, $100 \mathrm{mM} \mathrm{NaCl}, 1 \mathrm{mM}$ EDTA Amresco PH 8).

Preparation of viral RNA. Viral RNA was extracted using the standerd procedures (Jackwood et al., 1996 and Jackwood and Jackwood 1997). viral RNA was extracted from proventricular homogenates and the vaccinal strain of IBDV. One volume of each viral sample was extracted with an equal volume of chloroform, the aquous layer was collected. SDS (Amresco), and proteinase K (Sigma) were added to the final concentration of $0.5 \%$ and $1 \mathrm{mg} / \mathrm{ml}$ respectivelly. Following incubation at $37^{\circ} \mathrm{C}$ for $1 \mathrm{~h}$, the samples were extracted with equal volume of acid phenol $\mathrm{pH} 4.3$ (Sigma) and then chloroform: isoamyle alc (24:1). Viral RNA was then precipitated with cold ethanol and centifugation at $10,000 \mathrm{rpm} / \mathrm{min}$. for $10 \mathrm{~min}$. Viral RNA was resuspended in $100 \mu 1$ DMSO (90\%). Proventriculi from non infected SPF chicks were homogenized and exposed to RNA extraction and RT/ PCR- RFLP assay cDNA syntheseis. $5 \mu \mathrm{l}$ of total RNA was used in cDNA synthesis. Viral RNA was denatured at $95^{\circ} \mathrm{C}$ for $5 \mathrm{~min}$. followed by addition of RT reaction buffer medium containing $1 \mu \mathrm{g}$ of viral RNA, $2 \mu \mathrm{l}$ of $10 \mathrm{x}$ buffer RT buffer, $0.5 \mathrm{mM}$ of each dNTPs, $10 \mu$ of RNAse inhibitor (Fermentas Company), 10 pmol. of each specific primer and 4U reverse transcriptase enzyme (Fermentas Company) in total volume of $20 \mu 1$. The mixture was incubated at $42{ }^{\circ} \mathrm{C}$ for 1h. Primers (700-5' and 700-3') used in RTPCR were designd according to (Jackwood and Sommer 1997). These primers flanked $743 \mathrm{bp}$ fragment of VP2 gene from bp 701 to 1444.

The PCR. PCR was conducted accordintg to (Nassif, 2001). The optimal reaction mixture contained $1 \mu \mathrm{g}$ RT product, $5 \mu \mathrm{l}$ of $10 \mathrm{x}$ buffer, $200 \mu \mathrm{M}$ of each dNTPs, $30 \mathrm{pmol}$ of each primer, $\mathrm{MgCl}_{2}(2-4 \mathrm{mM})$ and $2.5 \mathrm{U}$ Taq polymerase (Fermentas Company). in a rection contaning and. Primers were used at a concentration of. The PCR was performed using thermal cycler (T-gradiant PCR, Biometra) in a program that involved initial denature at $94^{\circ} \mathrm{C}$ for $3 \mathrm{~min}$. followd by 25 cycles of denature at $94^{\circ} \mathrm{C}$ for $1 \mathrm{~min}$., annealing at $55^{\circ} \mathrm{C}$ for $1 \mathrm{~min}$., extension at $72^{\circ} \mathrm{C}$ for $1 \mathrm{~min}$ and final extension at $72^{\circ} \mathrm{C}$ for $10 \mathrm{~min}$. The amplicon was visualized on $1.5 \%$ agarose under U.V illumination. A 100bp DNA ladder (Fermentas Company) was used.

RFLP assay. RFLP assay was performed according to (Jackwood and Sommer, 1997). The amplicon was $1^{\text {st }}$ purified using PCR product purification kit, then digested using the restriction enzyme BstOl and $\mathrm{Mbol}$ separatly according to the manufacturer's instructions. Briefly, $1 \mu \mathrm{g}$ of amplicon was digested for $1 \mathrm{~h}$ at $60^{\circ} \mathrm{C}$ for BstO1 and $37^{\circ} \mathrm{C}$ for Mbo1, following the incubation the restriction fragment was separeted on $1.5 \%$ agarose gel utilizing 100bp DNA ladder and $123 \mathrm{bp}$ ladder. Purification kit and restriction enzymes were obtained from Fermentas Company.

\section{Results}

The RT-PCR products from the 3 proventricular homogenates and the D78 vaccinal strain of IBDV were identical to

Table (1): RFLP profile of the IBDV field isolates and D78 vaccinal strain.

\begin{tabular}{|c|c|c|c|c|c|c|c|c|c|c|}
\hline \multirow{2}{*}{$\begin{array}{l}\text { Code No. } \\
\text { of the strain }\end{array}$} & \multicolumn{5}{|c|}{ BstOI } & \multicolumn{5}{|c|}{ MbOI } \\
\hline & 424 & 209 & 172 & 154 & 119 & 403 & 362 & 280 & 269 & 229 \\
\hline Field isolate (1) & & & & & & & & & & \\
\hline Field isolate (2) & & & & & & & & & & \\
\hline Field isolate (3) & & & & & & & & & & \\
\hline D78 & & & & & & & & & & \\
\hline
\end{tabular}




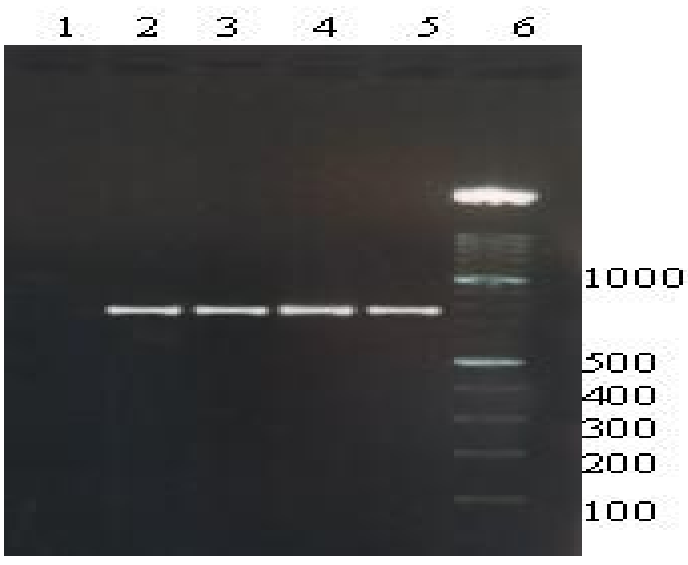

Fig. (1): RT/PCR products of the 3 proventricular homogenates of naturally infected flocks with TVP, D78 vaccinal strain and proventricular homogenate of noninfected negative control

Lane 1: Non-infected proventricular homogenate. Lane 2: D78 vaccinal strain.

Lane 3, 4, 5: Naturally infected proventricular homogenate. Lane 6: 100 bp ladder.

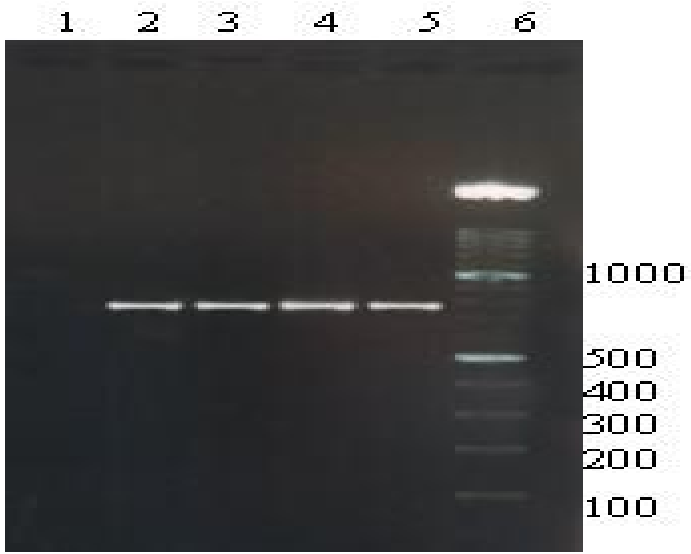

Fig. (2): RFLP of the PCR products of the 3 IBDV field isolates and $D 78$ strain using BstOI enzyme

Lane 1: D78 vaccinal strain

Lane 2, 3, 4: The 3 IBDV field isolates

Lane 5: 100 bp ladder

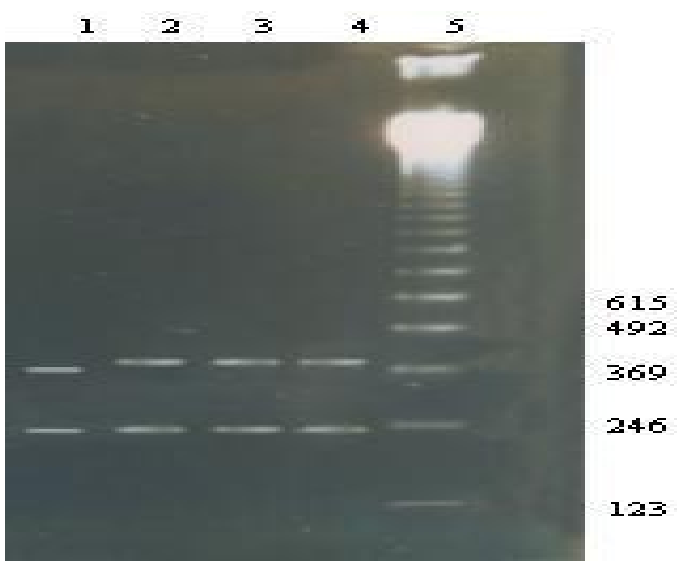

Fig. (3): RFLP of the PCR products of the 3 IBDV field isolates and D78 strain using MboI enzyme

Lane 1: D78 vaccinal strain

Lane 2, 3, 4: The 3 IBDV field isolates

Lane 5: 123 bp ladder each other and were of 743 bp length (Fig. 1). No RT/PCR product was detected from the proventricular homogenate of the negative control SPF chicks (Fig. 1). The results of RFLP assay for the 3 field isolates of IBDV and the D78 vaccinal strain are summarized in Table (1). The RFLP patterns of the 3 IBDV field isolates were similar to each other when digested with Bst01 enzyme and yielded 3 fragments of 424, 172 and $119 \mathrm{bp}$ in length (Fig. 2). On the other hand, the RFLP pattern of the D78 vaccinal strain was differed and 4 fragments of 209, 172, 154 and 119 bp were produced (Fig. 2). The RFLP profiles of the 3 IBDV field isolates; when $M b o 1$ enzyme was used, were also identical to each other and 2 fragments of $403 \mathrm{bp}$ and $229 \mathrm{bp}$ length were generated (Fig. 3 ), while 2 fragments of 362 and 229 bp length were produced when the PCR product of the D78 strain was digested with Mbol enzyme (Fig. 3).

Results of RT/PCR-RFLP assay denoted that the 3 IBDV field isolates were related to the same IBDV strain which is identical to Del/E variant strain of IBDV.

\section{Discussion}

The present study reports the detection and identification of IBDV associated with TVP in broiler chicken in Egypt. The detection and identification of IBDV in the present study using RT-PCR/RFLP from the proventricular homogenates confirms that it could be the a potential cause of the TVP. Our results are in agreement with that reported by (Bayyari et al., 1995, Goodwin et al., 1995 and 1996 and Hussein et al., 2003).

In the present study, RT/PCR-RFLP assay was used for detection and identification of the IBDVs from 3 proventricular homogenates in addition to D78 vaccinal strain. The primers were designated to amplify a $743 \mathrm{bp}$ fragment of the VP2 gene from bp 701 to bp 1444. The RT/PCR products of the 3 field isolates of IBDVs and D78 vaccinal strain were of the same size (743 bp length). Similar results were obtained by Jackwood and Sommer (1998).

RT-PCR/RFLP assay is used to differentiate the IBDV strains into 6 molecular groups, IBDV strains within a group were genitically and antigenically related molecular group 1 and 2 contained variant viruses; groups 3, 4 and 6 contained classic viruses, the molecular group 5 contained the Leukert strain viruses, (Jackwood and Jackwood, 1997 a,b and Jackwood, 1998 and Jackwood and Sommer, 1999). 
In our study, the results of RFLP assay on 3 field isolates of IBDV; using $\mathrm{MboI}$ and BstOI enzymes; conffirms that the 3 isolates are variant strains of IBDV they were identical to each other and related to the molecular group 2 of IBDVs that containing the Del/E variant strain (Fig 2,3). On the other hand, the RFLP assay of D78 vaccinal strains affirms; as expected; that is related to molecular group 4 that contains the classical strains. Our results are in agreement with that of (Hussein et al., 2003) who detected the same variant strain of IBDV; from broiler flocks that were suffered from proventriculitis in Egypt, using antigen capture ELISA. Many Egyptian authors reported the presence of variant strains of BDV in Egypt; (El-Sanousi et al., 1994, Sultan, 1995 and Metwally et al., 2003) who detected IBDV variant strains in broiler flocks in $58.3 \%$ of the tested bursae. The majority of the detected variants, in such study were related to Del/E strain of IBDV. This variant strain is identified at the molecular level for the first time in Egypt. Further investigations are required to investigate pathogenesis, pathogenicity, the immunosuppressive potentiality of this variant strain in chickens. Trials for preparation of inactivated vaccine from this variant strain is highly commandable.

\section{Acknowledgement}

The authors express their great thanks to Dr. Khalid S. Shaaban, lecturer of Poultry Diseases, Fac. Vet. Med., Cairo Univ., Egypt, for his great help in collecting field samples of proventriculus.

\section{References}

Bayyari, G. R.; Huff, W. E.; Baolg, J. M.; Rath, N. C. and Beasley, J. W. (1995): Experimental reproduction of proventriculitis using homogenates of proventricular tissue. Poult. Sci., 74: 1799-1809.

Cookson, K. C. (2001): Studies investigating the potential association between infectious bursal disease virus and infectious proventriculitis. Partnerships in Poultry, Paris, Pp. 30-33.

Dormitorio, T.; Giambrone, J.; Hoerr, F.; Kelly, T. and Lockaby, S. (2000): Is infectious bursal disease virus a cause of proventriculitis? Highlights of Agricultural Research, 47 (4)

El-Sanousi, A. A.; Maddbouly, H.; Saber, N. S.; ElBagouri, G. F.; Abdel-Bar, N. A.; Batrawi, A. and Reda. I. M. (1994): infectious bursal disease virus infection among Egyptian poultry flocks: III. Antigenitic characterization of infectious bursal disease virus by the antigen capture ELISA (AC-ELISA) using monoclonal antibodies (MAbs). Beni-Suef Vet. Med. Res.,300-307.

Giambrone, J. (2002): Infectious bursal disease virus: an old foe changes its facer again. Education development magzine, pp.:10.

Goodwin, M. A. (1993): Runting, stunting, enteritis and failure to thrive. AAAP Symposium on newly emerging and Re-emerging avian diseases: Applied Research and Practical Applications for Diagnosis and Control, program of the $130^{\text {th }}$ Ann. Meeting Am. Assoc. Avian Pathol., Minneapolis, MN., pp. 18-29.

Goodwin, M. A.; Latimar, K. S.; Player, E.; Niagro, E. and Campagnoli, R. (1995): Viral proventriculitis in chickens, program, $132^{\text {nd }}$ Ann. Meeting of the Am. Vet. Med. Assoc. Pittsburgh Pensylvania, 8-12, p. 140. Goodwin, M. A.; Hafner, S.; Bounous, I. D.; Latimer, K.; Player, E.; Niagro, E.; Campagnoli, R. and Brown, J. (1996): Viral proventriculitis in chickens. Avian Pathol., 25: 369-379.

Huff, G. R.; Zheng, Q.; Newberry, L. A.; Huff, W. E.; Baleg, J. M.; Rath, N. C.; Kim, K. S.; Martin, E. M.; Goeke, S. C. and Skeels, J. K. (2001): Viral and bacterial agents associated with experimental transmission of infectious proventriculitis of broiler chickens. Avian Dis., 45: 828-843.

Hussein, H. A.; Aly, A. M.; Sultan, H. and Al-Safty, M. (2003): Transmissible viral proventriculitis and stunting syndrom in broiler chickens in Egypt: 1 . Isolation and characterization of variant infectious bursal disease virus (IBDV). Vet. Med. J., Giza, 51 (3): 445-462.

Jackwood, D. J. (1998): Molecular identification of infectious bursal disease virus strains. Vinaland Update 62: pp. 4.

Jackwood, D. J. and Jackwood, R. J. (1997a): Molecular identification of infectious bursal disease virus strains. Avian Dis., 41: 97-104.

Jackwood, D. J. and Sommer, S. E. (1997b): Restriction fragment length polymorphism in the VP2 gene of infectious bursal disease viruses. Avian Dis., 41: 627-637.

Jackwood, D. J. and Sommer, S. E. (1998): Genetic heterogenicity in the VP2 gene of infectious bursal disease virus detected in commercially reared chickens. Avian Dis., 42: 321-339.

Jackwood, D. J. and Sommer, S. E. (1999): Restriction fragment length polymorphism in the VP2 gene of infectious bursal disease virus from outside the United States. Avian Dis., 43: 310-314.

Jackwood, D. J.; Haues, G. and Heinmillar, S. (1996): Infectious bursal disease viral RNA amplification using RT/PCR from bursal tissue following phenol: chloroform inactivation of the virus. Avian Dis., 40: 457-460.

McNulty, M. S. (1991): Runting stunting syndrome in broiler chickens. Proceed. Poult. Hlth. Condem., Ocean City, Maryland, pp. 115-124.

Metwally, A. M.; Sabry, M. Z.; Omer, M. M.; Yousif, A. A. and Reda, I. M. (2003): Direct detection of variant infectious bursal disease virus in vaccinated Egyptian broiler flocks using antigen-capture ELISA. Vet. Med. J., Giza, 51 (1): 105-119.

Nassif, S. A. (2001): A trial for preparation and evaluation of a local live infectious bursal disease virus vaccine. Ph.D. Thesis, Fac. Vet. Med., Cairo Univ., Egypt.

Newberry, L. A. (1996): Determination of the role of standard and variant strains of infectious bursal diseasevirus in induction of viral proventriculitis in 
chickens. Ph.D. Dissertation Univ. of Arkansas, Fayelteville, AR.

Skeels, J. K.; Newbarry, L. A.; Beasley, J. N. and Hopkins, B. A. (1998): Histologic comparison of lesions induced in the proventriculus and other areas of the intestinal tract of chicken experimentally infected with classic and variant strains of infectious bursal disease virus. Poult. Sci., 77: 133.

Sultan, H. A. (1995): Studies on infectious bursal disease in chickens. Ph.D. Thesis, Fac. Vet. Med., Alexandria Univ., Egypt. 